\title{
The Influence of Self-Control and Mindfulness on Counterproductive Academic Behavior
}

\author{
Zainnur M. Rusdi ${ }^{1^{*}}$ \\ ${ }^{1}$ University of Lampung, Bandar Lampung, Indonesia
}

\begin{abstract}
Some forms of academic behavior of counter-productive that many college students are doing is plagiarism, cheating, absenteeism, and postponing the task. Counterproductive academic behavior such as plagiarism and cheating among students can be reduced if the student has self-control and good mindfulness. This study aims to examine the negative effects of self-control and mindfulness on counter-productive academic behavior. The results of hypothesis testing showed that each variable of self-control and mindfulness have positive effect on counterproductive academic behavior. The low mean value in this study indicates that the average of college students who become respondents have a low level of self-control and low mindfulness that has a tendency to perform counterproductive academic behavior.
\end{abstract}

Keywords: Counterproductive Academic Behavior, Mindfulness, Self-Control

\section{INTRODUCTION}

University is the center of scientific activity that includes teaching, research, and community service, known as "tridharma". "Tridharma" must be implemented consistently and qualified to ensure the quality of education. Continuous improvement of education quality will produce graduates who are able to work and contribute in building society. The quality of education in Indonesia compared to other ASEAN countries is still far behind, so the quality improvement must be implemented intensively. The ranking of education system in Indonesia occupies position 69 of 76 countries, while Singapore is ranked one (www.bbc.com, 2015). One indicator of the quality of education is the number of scientific publications in accredited national journals and international journals. Based on the SCImago portal it is known that Indonesia is ranked 61st out of 239 countries with 25,481 publications. Indonesia is far behind ASEAN neighboring countries such as Malaysia, which ranks 37th with the number of scientific publications 125,084, Singapore which is ranked 32nd with the number of publications 171,037, and Thailand at number 43 with the number of publications 95,690 (www.nasional.sindonews.com, 2015).

Publication of scientific papers can be improved through academic culture that is reading and writing early because the lack of reading culture will cause difficulties for lecturers and students to analyze various things and convey the subject into writing. Based on the results of the UNESCO study in 2013, in Indonesia only one person out of 1000 people who like to read and BPS survey in

* Corresponding author. Email address: zainnur@gmail.com 
Indonesia in 2013 showed that the people of Indonesia most liked to watch television, that is as much as $91.68 \%$ while those who read the newspaper only $17.6 \%$ (www.suara.com, 2015).

Lack of interest in reading also makes most students unable to produce quality scientific work. Such inability often results in a lazy and instant attitude in the form of copy-paste works of others. It certainly leads to counterproductive academic behavior. Hakstian et al. (2002) explains that counterproductive behavior is a behavioral that harms organizational and or workgroup objectives - behavioral abuses such as property, drug and alcohol theft, dishonesty, disruptive behavior, failing to meet standards, absences, delays, and lack of effort. Some forms of academic behavior of counter-productive that many college students are doing is plagiarism, cheating, absenteeism, and postponing the task. Professor of Political Science from Northwestern University, Chicago United States, Jeffrey A Winters, claimed to still find plagiarism in the writing of academic essay of Indonesian students, this indication of plagiarism often appears in the selection of academic writing contest in 2015 ISRSF held in Indonesia which is about a quarter of the entry essay Do plagiarism in large quantities (www.tempo.co.id, 2016).

Plagiarism has also increased in several overseas universities not only in Indonesia. According to a report by The West Australian figures obtained from four universities in Western Australia this indicates that in the past two years, 4,000 students have received warnings or disciplinary action for including noncopyrighted work, collaborating or cheating during exams, the previous year only 2,000 cases (www.internasional.kompas.com, 2013). In addition to plagiarism, cheating culture among students shows an alarming rate. Assessment based on the outcome and not based on the process contributes to the culture of cheating. Counterproductive academic behavior such as plagiarism and cheating among students can be reduced if the student has self-control and good mindfulness.

According to Tangney et al. (2004), self-control is the ability of the existing response in a person to refrain from negative behavior. Self-control has a negative influence on counterproductive academic behavior or in other words the higher one's self-control will be less likely to engage in counterproductive academic behavior (Zettler, 2011). The insertion of citation and paraphrasing the opinions of others as a form of self-control can prevent and reduce plagiarism among students. Mindfulness describes a conscious state characterized by clarity and clarity to the functions and experiences that occur today (Brown and Ryan, 2003). Higher mindfulness will reduce counterproductive academic behavior (Schwager, 2015), through awareness of the importance of reading, writing early on, and value-based judgments not only of the final outcome, can reduce counter-productive academic behavior. Counterproductive academic behavior is our responsibility to be prevented and minimized, resulting university graduates who are professional, moral, and innovative.

\section{LITERATURE STUDY AND HYPOTHESES DEVELOPMENT Self-Control}

According to Tangney et al. (2004), self-control is the ability of the existing response in a person to refrain from negative behavior. Individuals with high selfcontrol seem more able to consider the possible long-term consequences of their behavior therefore they adhere to goals such as completing tasks on time, and more 
likely to avoid actions with undesirable long-term consequences such as substance abuse (Zettler, 2011) .

\section{Mindfulness}

Mindfulness describes a conscious state characterized by clarity and clarity to the functions and experiences that occur today (Brown and Ryan, 2003). Schwager (2015) explains the definition of mindfulness as a state of consciousness in which the individual is aware of what is happening right now with a nonjudgmental attitude. The relationship between mindfulness and self-control is negatively related to negative behavior (Tangney et al, 2004; Schwager, 2015).

\section{Counterproductive Academic Behavior}

Counterproductive academic behavior is a negative behavior that harms the organization as quoted from Hakstian et al. (2002) misuse of behaviors such as property theft, drugs and alcohol, dishonesty, disruptive attitudes, failing to meet standards, absenteeism, delay, and lack of effort are forms of counter-productive academic behavior.

\section{Self-Control and Counterproductive Academic Behavior}

Based on a study conducted by Zettler (2011) on social psychology students, explaining that self-control influenced the counterproductive academic behavior, a person with high self-control had a negative effect on counterproductive academic behavior $(\mathrm{r}=-0.57, \mathrm{p}<0.005)$.

Ha1: Self-control negatively affects counterproductive academic behavior.

\section{Mindfulness and Counter-Productive Academic Behavior}

Schwager et al. (2015) conducted a study on 281 students, the results obtained from the study that mindfulness negatively affect the counterproductive academic behavior $(\beta=-0.13, \mathrm{p}<0.05)$.

Ha2: Mindfulness negatively affects counterproductive academic behavior.

\section{RESEARCH METHODOLOGY}

\section{Operational Definition and Variable Measurement}

Variables used in this study consist of independent variables (X) and dependent variable (Y). Independent variables are self-control (X1) and mindfulness (X2), while the dependent variable is counterproductive academic behavior (Y).

\section{Self-control}

According to Tangney et al. (2004), self-control is the ability of the existing response in a person to refrain from negative behavior. Self-control is measured using the Self-Control Scale Brief by Tangney et al. (2004) as many as 13 items statement. Scale used $1=$ STS (strongly disagree) up to $5=$ SS (strongly agree), example item is "I'm lazy", or "I'm hard to concentrate".

\section{Mindfulness}

Mindfulness describes a conscious state characterized by clarity and clarity to the functions and experiences that occur today (Brown and Ryan, 2003). The quality of consciousness was measured using Mindful Attention Awareness Scale (MAAS) by Brown and Ryan (2003) as many as 15 items statement. Scale used 1 
$=$ STS (strongly disagree up to $5=$ SS (strongly agree), an example statement item is "I find it hard to focus on things happening right now".

\section{Counterproductive Academic Behavior}

According to Hakstian et al. (2002), counterproductive behavior is a negative behavior that harms the organization - behavioral abuses such as property, drug and alcohol theft, dishonesty, disruptive behavior, failing to meet standards, absences, delays and less effort. Counter-productive academic behavior is measured using inventory of counterproductive behavior "During the exam, seeing and getting information from peer paper".

\section{Data Collection Method}

Researcher use questionnaires to obtain data, because the study designs using survey. Questionnaires are distributed directly to respondents. Respondents were given time to fill out the questionnaires.

\section{Population and Sample}

The population in this study is undergraduate student university in Bandar Lampung. The sample in this research was determined by using non probability sampling method with convenience sampling technique. Roscoe (1975) in Sekaran and Bougie (2010) explain that sample sizes greater than 30 and less than 500 are appropriate for most studies. The sample used 200 respondents.

\section{Research Model}

The research model can be seen in Figure 1 below:

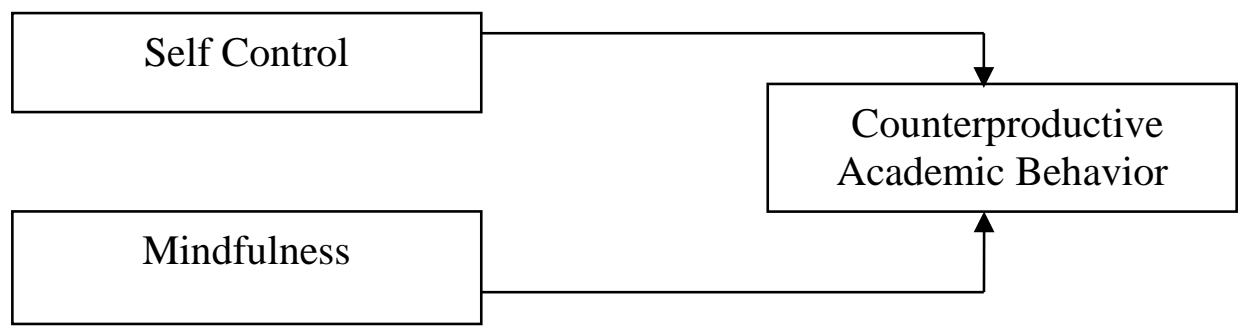

Figure 1 Research Model

\section{Validity Test and Reliability Test of Research Instruments}

Validity test is done by using Confirmatory Factor Analysis (CFA) to obtain construct validity by using factor analysis. Test reliability is using Cronbach's Alpha value. The value of Cronbach's Alpha coefficient $\leq 0.6$ signifies bad reliability, reliability value between 0.6 to 0.7 is acceptable, and if it exceeds 0.8 , reliability is good (Sekaran and Bougie, 2010).

\section{Data Analysis Technique}

Data analysis techniques used are simple regression and multiple regression. Regression is used to determine the effect of independent variables (X) on the dependent variable (Y). A simple regression uses one independent variable to the dependent variable, whereas multiple regressions use more than one independent or dependent variable.

Regression equation in this research is:

$$
\begin{aligned}
& Y=a+b 1 X 1+e t \\
& Y=a+b 2 X 2+e t
\end{aligned}
$$


Information:

$\mathrm{Y}=$ counterproductive academic behavior

$\mathrm{a}=$ constants

$\mathrm{b} 1=$ regression coefficients of variable $\mathrm{X} 1$

$\mathrm{b} 2=$ regression coefficient of variable $\mathrm{X} 2$

$\mathrm{X} 1=$ self-control

$\mathrm{X} 2=$ mindfulness

\section{RESULTS}

\section{Validity and Reliability Test Results}

The results of the validity test of the research questionnaire showed the value of KMO and Bartlett's Test for Self-Control (SC) of 0.685 ( $\mathrm{p}<0.05$ ), Mindfulness (M) of 0.738 ( ( p <0.05), and Counterproductive Academic Behavior (CAB) (P $<0,05)$ At the time of validity test of SC there are 3 item that must be removed because of factor loading $<0,5$ that is $\mathrm{SC} 2, \mathrm{SC} 3$, and $\mathrm{SC} 13$ Four item in variable $\mathrm{M}$ that is M5, M8, M9, And M12, and 3 item on CAB variables should also be deleted i.e. $\mathrm{CAB} 4, \mathrm{CAB} 5$, and $\mathrm{CAB} 17$ because the items has a factor loading $<0.5$ and cross loading occurred. The reliability test results show the cronbach's alpha value of $0.545(\mathrm{SC}), 0.679(\mathrm{M})$, and $0,898(\mathrm{CAB})$.

\section{Hypotheses Testing Results}

Hypotheses testing results do not support the first and second hypothesis. The following summarizes the hypotheses test in Table 1.

Table 1 Hypotheses Testing Results

\begin{tabular}{ll}
\hline \multicolumn{1}{c}{ Hypotheses } & \multicolumn{1}{c}{ Description } \\
\hline Ha1: Self-control negatively affects & Not supported $(\beta=0,499079, \mathrm{t}=$ \\
counterproductive academic behavior & $8,104112, \mathrm{p}<0,05)$ \\
& Mean Self-Control =2,435 \\
& Mean CAB $=2,73$ \\
& The results show that self-control has \\
& a positive effect on counterproductive \\
& academic behavior \\
\hline Ha2: Mindfulness negatively affects & Not supported $(\beta=0,452941, \quad \mathrm{t}=$ \\
counterproductive academic behavior. & $7,148797, \mathrm{p}<0,05)$ \\
& Mean Mindfulness $=2,21$ \\
& Mean CAB $=2,73$ \\
& The results show that mindfulness has \\
& a positive effect on counterproductive \\
& academic behavior \\
\hline
\end{tabular}

\section{DISCUSSION}

The test results using linear regression explains that self-control has a positive effect on counterproductive academic behavior where the hypothesis proposed is self-control has a negative effect on counterproductive academic behavior. The results of these analyzes have shown that the level of self-control of college students have an influence on the tendency of individuals with counterproductive academic behavior. In this study, the low mean results indicate that the average of 
students who become respondents have a low level of self-control that has a tendency to perform counterproductive academic behavior. As Zettler (2011) argues that a person with a high degree of self-control will have a negative tendency toward counterproductive academic behavior, and otherwise a person with low self-control will have a positive tendency toward counterproductive academic behavior.

The result of data analysis also shows that mindfulness have positive effect on counterproductive academic behavior, this result is in contrast to the second hypothesis that states mindfulness negatively affect the counterproductive academic behavior. These results indicate a low level of mindfulness that will tend to engage in counterproductive academic behavior, where these results are characterized by a low mean value. Schwager et al. (2015) explains that the level of mindfulness will determine the tendency of students to engage in counterproductive academic behavior. The higher the level of mindfulness then negatively affect the counterproductive academic behavior, and the lower the level of mindfulness then positively influence on counterproductive academic behavior.

\section{CONCLUSIONS}

Self-control and mindfulness affect the counterproductive academic behavior. However, the influence of self-control and mindfulness can be positive or negative depending on the level of self-control and mindfulness possessed by the student. Therefore, to reduce the tendency of counterproductive academic behavior, students should be aware with self-control and mindfulness, realize that any form of counterproductive academic behavior can bring negative results that will adversely affect students. The university should continue to socialize the adverse impacts of counterproductive academic behavior for students through the implementation of academic rules with full discipline and improvement of academic and non academic skills through seminars and various training that benefit the students.

\section{References}

/2015/11/27/131119/ pemerintah-akui-minat-baca-di-indonesia-masih-rendah [accessed on March 2nd 2016].

(2015). Available at (http://www.bbc.com/indonesia /majalah/2015/05/ 150513_majalah_asia_sekolah_terbaik. [Accessed on March 3rd 2016]

Brown, K. W., \& Ryan, R. M. (2003). The Benefits of Being Present: Mindfulness and Its Role in Psychological Well-Being. Journal of Personality and Social Psychology, 84(4), 822-848.

Hakstian, A. R., Farrell, S., \& Tweed, R. G. (2002). The Assessment of Counterproductive Tendencies by Means of the California Psychological Inventory. International Journal of Selection and Assessment, 10(1/2), 58-86. 
Schwager, I. T. L., Hülsheger, U. R., \& Lang, J. W. B. (2015). Be Aware To Be on The Square: Mindfulness and Counterproductive Academic Behavior. Personality and Individual Differences, 1-6.

Sekaran, U., \& Bougie, R. (2010). Research methods for business. United Kingdom: John Wiley \& Sons Ltd.

Subekti, N. A. (2015). Available at http://nasional.sindonews.com/read 1988644/162/ rangking-publikasi-ilmiah-internasional-indonesia1428903924 [accessed accessed on March 3rd 2016.

Tangney, J. P., Baumeister, R. F., \& Boone, A. L. (2004). High Self-Control Predicts Good Adjustment, Less Pathology, Better Grades, and Interpersonal Success. Journal of Personality, 72(2), 271-322.

Tarigan, M. (2016). Seperempat Esai Mahasiswa Indonesia Terindikasi Plagiat. Available at https://m.tempo.co/read/news/ 2016/02/09/079743504/ seperempat-esai-mahasiswa-indonesia-terindikasi-plagiat. [Accessed on March 2nd 2016].

Wijaya, L. S. (2013). Semakin banyak mahasiswa di Australia Menjadi Plagiat. Available at.http://internasional.kompas.com/read /2013/04/19/09161797/ Semakin.Banyak.Mahasiswa.di.Australia.Menjadi.Plagiat. [Accessed on March 2nd 2016]

Zettler, I. (2011). Self-control and academic performance: Two field studies on university citizenship behavior and counterproductive academic behavior. Learning and Individual Differences, 21, 119-123. 